\title{
Morphological and ultrastructural characterization of the coelomocytes in Apostichopus japonicus
}

\author{
Kun Xing ${ }^{1,2}$, Hong Sheng Yang ${ }^{1, *}$, Mu Yan Chen ${ }^{1,2}$ \\ ${ }^{1}$ Institute of Oceanology, Chinese Academy of Sciences, 7 Nanhai Road, Qingdao, Shandong 266071, PR China \\ ${ }^{2}$ Graduate School, Chinese Academy of Sciences, Beijing, PR China
}

\begin{abstract}
The coelomocytes suspended in the coelomic fluid and occurring in the coelomic epithelial layer of the sea cucumber Apostichopus japonicus (Selenka) (Holothuroidea: Aspidochirota: Stichopodidae) function as mediators of the immune system, trephocytic cells and nutrient transport cells. Types of coelomocytes are characterized based on their morphological and ultrastructural features. Flow cytometry plus light and electron microscopic analyses were conducted in order to characterize the coelomocytes of A. japonicus. Six types of coelomocytes were identified: lymphocytes, morula cells, amoebocytes, crystal cells, fusiform cells and vibratile cells. Within these major categories, several distinctive cell types occurred that might represent developmental stages. The mean \pm SD coelomocyte concentration in the individuals (body length: 10 to $15 \mathrm{~cm}$; weight: 100 to $150 \mathrm{~g}$ ) was $(3.79 \pm 0.65) \times 10^{6}$ cells ml ${ }^{-1}$. The coelomic fluid contained mainly hyalinocytes $(76.69 \%)$ and granulocytes $(23.31 \%)$.
\end{abstract}

KEY WORDS: Sea cucumber $\cdot$ Coelomocyte $\cdot$ Morphology $\cdot$ Ultrastructure

\section{INTRODUCTION}

Sea cucumbers, especially Apostichopus japonicus, are among the most economically important and commercially exploited organisms in East Asia. Currently, with the increasing market demand, there is a real risk of over-exploitation of wild sea cucumbers. Mass mortality occurring in cultivated sea cucumbers has resulted in great economic losses for China. Most current studies have focused on aquaculture and management, while basic studies on cytology and histology have received little attention. It is necessary to gain a systematic understanding of the basic biology of $A$. japonicus in order to protect it in the wild.

Compared with other invertebrate phyla, sea cucumbers possess a number of unique features, the most remarkable of which are a water vascular system and a blood system containing coelomocytes. The coelomocytes are produced by a pseudostratified layer of coelomic epithelial cells that cover the interior of the body wall, the outer surfaces of the digestive and reproductive systems, and the inner surfaces of the water vascular system (Hyman 1955). The free coelomocytes in the coelomic cavity of sea cucumbers are thought to participate in gas exchange, transport of nutrients, nutrient storage, clot formation, excretion of waste products, production of some components of the connective tissue, and immune defence (Mary 1972, Eliseikina \& Magarlamov 2002).

The diversity and classification of echinoderm coelomocytes have been underestimated, and, therefore, the assignment of cell types to specific roles has been inadequate. The coelomocytes of Apostichopus japonicus are well developed and structurally specialized for the functions of the water vascular system. There are great variations in coelomocyte compositions among different specimens, and the types of coelomocytes even vary from one coelomic compartment to another in a single specimen (Hetzel 1963). Earlier classification of echinoderm coelomocytes, which was based on light microscopy and histochemistry, included at least 9 general descriptions of holothurian coelomocytes 
(Hetzel 1963, Lecal 1980, Messer \& Wardlaw 1980, Edds 1993). More recently, electron microscopy has provided extensive ultrastructural details of the coelomocytes of echinoderms (Chia \& Xing 1996, Eliseikina \& Magarlamov 2002, Liu et al. 2005) and has supplied well-defined features of specific cell types within the coelomic epithelia (Massin 1980, Holland 1984), thereby offering new insights into the range of coelomocytes found in the coelomic fluid.

Echinoderm coelomocytes have been postulated to play an important role in humoral and cellular immune responses. The internal defence system of Apostichopus japonicus consists of circulating coelomocytes. The morula cells may release some humoral defence factors, such as lysins, agglutinins and antioxidant enzymes (Dolmatova et al. 2004). The coelomocytes mediate the cellular responses to immune challenges through phagocytosis, encapsulation, cytoxicity and the production of antimicrobial agents (Smith et al. 1992, Gross et al. 1999).

In the present study, we describe the morphological and ultrastructural characteristics of coelomocytes in Apostichopus japonicus and review previous studies.

\section{MATERIALS AND METHODS}

Coelomic fluid collection. Healthy sea cucumbers Apostichopus japonicus (body length: 10 to $15 \mathrm{~cm}$; weight: 100 to $150 \mathrm{~g}$ ) were obtained from aquatic farms in Qingdao, Shandong Province, China. The sea cucumbers were transferred to the laboratory in a 500 l PVC tank supplied with $10^{\circ} \mathrm{C}$ sand-filtered and aerated seawater, which was renewed daily. All animals were acclimatized for at least $4 \mathrm{wk}$ prior to the experiments. About 5.0 to $10.0 \mathrm{ml}$ of coelomic fluid (CF) was drawn from the right lateral side of the body (Santiago-Cardona et al. 2003) using a 25 gauge needle, and diluted with an equal volume of artificial seawater (ASW, pH 7.4); EDTA fixative $(6 \times$ $10^{-3} \mathrm{M}$ EDTA, $0.01 \mathrm{M}$ phosphate buffered saline [PBS], ASW, pH 6.0) (Noble 1970) was used as a disaggregating agent. The $\mathrm{CF}$ was stored in sterile $5 \mathrm{ml}$ centrifuge tubes at $4^{\circ} \mathrm{C}$.

Light microscopy. Fresh preparations and Wrightstained coelomocyte smears were examined, in which hyalinocytes, granulocytes, acidophilic and basophilic cells could be distinguished among the coelomocytes. The percentages of hyalinocytes and granulocytes were calculated from the Wright-stained smears. Total coelomocyte counts were made using a haemocytometer slide. Cell diameters were measured with an Opton Imaging system for 20 samples. Coelomocytes in fresh preparations were photographed using a Zeiss Imaging system.
Flow cytometry. The filtered fresh CF was fixed with an equal volume of $6 \%$ formalin solution in sterile, filtered seawater. Then, the subpopulations of the coelomocytes were determined from an FSC-SSC (forward scatter-sidewards scatter) plot for each sample. SSC and FSC analyses were conducted in a FACSvantage analyzer (BD, Biosciences) equipped with a Hewlett Packard computer analysis program.

Scanning electron microscopy. The fresh CF was fixed with $2.5 \%$ glutaraldehyde (v/v) in $0.1 \mathrm{M}$ PBS buffer solution ( $\mathrm{pH} 7.4$ ), washed in the buffer, postfixed with $1 \%$ osmium tetraoxide $(\mathrm{p} / \mathrm{v})$ in the same buffer, and dehydrated in a graded series of ethanol, followed by critical point desiccation with $\mathrm{CO}_{2}$; then, the specimens were mounted on aluminium stubs and sputter-coated with 10 to $20 \mathrm{~nm}$ of gold/palladium. Observation was done with a KYKY2800B scanning electron microscope, operated at a voltage of $25 \mathrm{kV}$.

Transmission electron microscopy. The fresh $\mathrm{CF}$ was extracted and centrifuged at $1000 \times g$ for $1 \mathrm{~min}$ at ambient temperature $\left(18\right.$ to $\left.20^{\circ} \mathrm{C}\right)$. The pellet of coelomocytes was fixed with $2.5 \%$ glutaraldehyde (v/v) for $12 \mathrm{~h}$, and the coelomocytes were washed in cuvettes buffered with $1 \%$ sucrose for $2 \mathrm{~h}$ at $4^{\circ} \mathrm{C}$. Semithin sections $(1 \mu \mathrm{m})$ were stained with $1 \%$ osmium tetroxide in $0.1 \mathrm{M}$ PBS buffer for $2 \mathrm{~h}$ at $4^{\circ} \mathrm{C}$. After being washed in 0.1 M PBS buffer, the coelomocytes were dehydrated in a graded ethanol series, and embedded in Epon812. Ultrathin sections (50 to $70 \mathrm{~nm}$ ) were stained with uranyl acetate and lead citrate for 30 and 5 min, respectively, and examined in a $\mathrm{H} 7000$ transmitting electron microscope operated at a voltage of $75 \mathrm{kV}$.

Statistical analyses. Data are presented as means, standard deviations and differences as computed with MINITAB Statistical Software (Version 14). One-way analysis of variance (ANOVA) was used to test differences among cell types. Differences are considered significant at a probability level of 0.05 .

\section{RESULTS}

\section{Light microscopy}

In Wright-stained smears, 2 coelomocyte types, hyalinocytes and granulocytes, were identified based on the presence or absence of cytoplasmic granules, respectively. Two types of hyalinocytes (large and small) differed greatly in shape and content. The presence of both large and small types of hyalinocytes suggest that they might be either 2 developmental stages of the same cell type, or 2 different types of hyalinocytes with similar staining properties. The small hyalinocytes contained central nuclei and scanty cytoplasm, with a 
Table 1. Apostichopus japonicus. Parameters of 4 types of coelomocytes in the coelomic fluid of the sea cucumber.

$\mathrm{N}$ : number of cells measured in Wright-stained smears

\begin{tabular}{|lccc|}
\hline \multirow{2}{*}{$\begin{array}{l}\text { Coelomocyte } \\
\text { types }\end{array}$} & $\mathrm{N}$ & \multicolumn{2}{c|}{ Cell diameter $(\mu \mathrm{m})$} \\
& & Mean $\pm \mathrm{SD}$ & Range \\
\hline Hyalinocytes & & $3.01 \pm 0.093$ & 2.10 to 3.90 \\
$\quad$ Small & 23 & $5.47 \pm 0.15$ & 3.00 to 9.60 \\
$\quad$ Large & 18 & & \\
Granulocytes & & $5.83 \pm 0.41$ & 4.50 to 6.60 \\
$\quad$ Small & 24 & $10.51 \pm 0.24$ & 9.00 to 12.90 \\
Large & 24 & $6.20 \pm 0.29$ & 2.10 to 12.90 \\
Total & 22 & & \\
\hline
\end{tabular}

mean size of $3.00 \mu \mathrm{m}$ (Table 1). The large hyalinocytes varied greatly in diameter, ranging from 3.00 to $9.60 \mu \mathrm{m}$; their single, round nucleus was located on one side of the cytoplasm and had an average (mean \pm SD) diameter of $2.94 \pm 0.078 \mu \mathrm{m}$, ranging from 2.40 to $3.60 \mu \mathrm{m}$. There were also small and large granulocytes (Table 1). Significant differences in cell size were found between the 4 types of coelomocytes (1-way ANOVA, p < 0.05), with the exception of the large hyalinocytes and small granulocytes.
Six coelomocyte types were identified by size and shape under light microscopy (LM) in fresh preparations. The lymphocytes exhibited 3 forms: round hyalinocytes (rh), hyalinocytes with 2 pseudopodia at opposite poles of the cell (ph), and triangular hyalinocytes with a filiform pseudopodium extension from each of the corners (th) (Fig. 1A). The thin hyaline cytoplasm of a morula cell contained granules that were uniform in size and completely filled the cell (Fig. 1B). In addition, crystal cells were commonly hexagonal (Fig. 1C). We failed to identify crystal cells using transmission electron microscopy (TEM). A few other coelomocytes were fusiform cells (Fig. 1D) and vibratile cells (Fig. 1E). In living preparations, the fusiform cells were spindle shaped with 2 single, long pseudopodia at the ends of the cells, while the vibratile cells were oval, with 1 long, large flagellum-like extension protruding from a basal granule. We failed to distinguish vibratile cells with TEM. Amoebocytes with petaloid and filiform pseudopodia were also identified in fresh preparations using LM (Fig. 1F,G).

The mean $\pm \mathrm{SD}$ concentration of coelomocytes in Apostichopus japonicus was $(3.79 \pm 0.65) \times 10^{6} \mathrm{cells} \mathrm{m}^{-1}$.
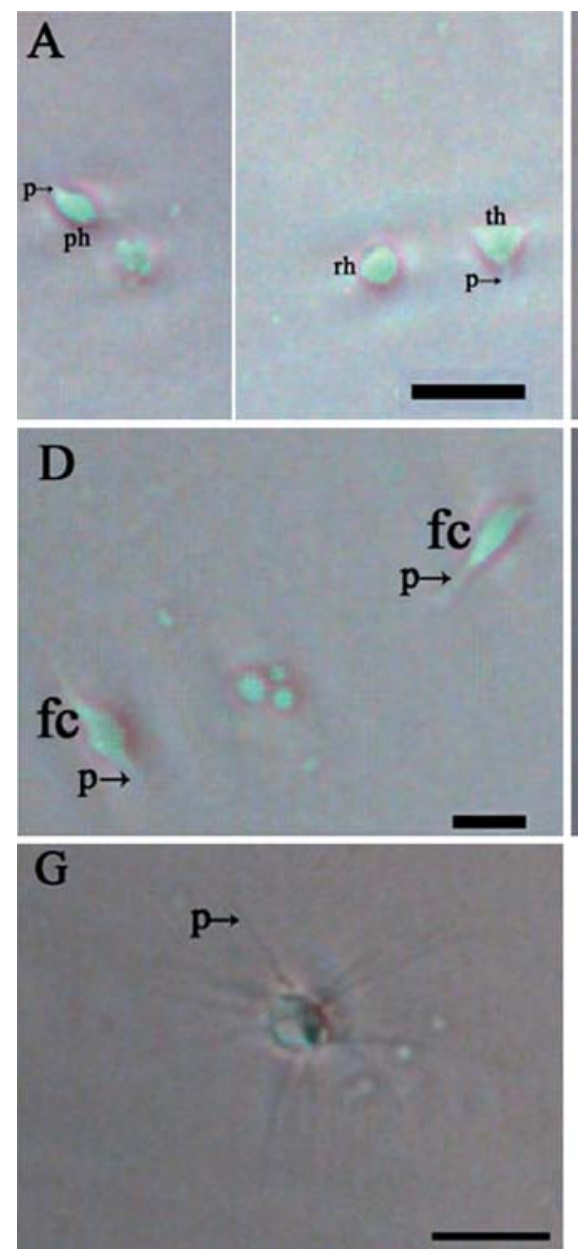
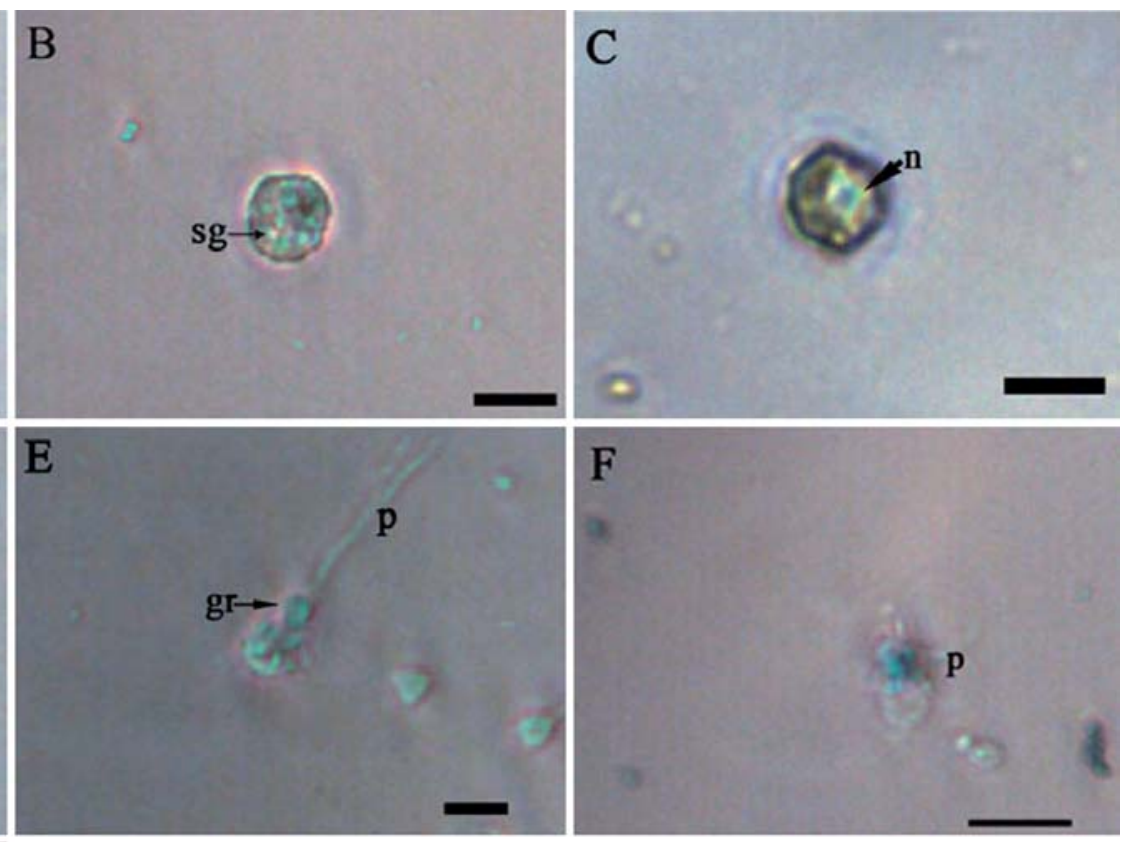

Fig. 1. Apostichopus japonicus. Light micrographs of coelomocytes of the sea cucumber. (A) Small hyalinocytes (scale bar: $10 \mu \mathrm{m}$ ); (B) large granulocyte (scale bar: $10 \mu \mathrm{m})_{i}(\mathrm{C})$ crystal cell (scale bar: $\left.5 \mu \mathrm{m}\right)_{i}$ (D) fusiform cells (fc) (scale bar: $5 \mu \mathrm{m}$ ); (E) vibratile cell (scale bar: $5 \mu \mathrm{m})$; $(\mathrm{F})$ petaloid amoebocyte (scale bar: $10 \mu \mathrm{m})$; (G) filiform amoebocyte (scale bar: $10 \mu \mathrm{m}$ ). Labels-rh: round hyalinocyte; ph: hyalinocyte with 2 pseudopodia; th: triangular hyalinocyte; p: pseudopodia; sg: secretory granules; n: nucleus; gr: granule 
Table 2. Apostichopus japonicus. Percentages of granulocytes and hyalinocytes in the coelomic fluid of the sea cucumber. $\mathrm{N}$ : number of view fields; sum: number of coelomocytes of different types as distinguished and counted on Wright-stained smears

\begin{tabular}{|lrrcc|}
\hline $\begin{array}{l}\text { Coelomocyte } \\
\text { types }\end{array}$ & N & Sum & $\begin{array}{c}\text { (\%) of total population } \\
\text { (Mean } \pm \text { SD) }\end{array}$ & $\begin{array}{c}\text { Total } \\
(\%)\end{array}$ \\
\hline $\begin{array}{l}\text { Hyalinocytes } \\
\quad \text { Small }\end{array}$ & 20 & 1235 & $59.83 \pm 3.24$ & 76.69 \\
$\quad$ Large & 20 & 343 & $16.85 \pm 1.53$ & \\
Granulocytes & & & & \\
$\quad$ Small & 20 & 245 & $11.89 \pm 1.29$ & 23.31 \\
Large & 20 & 238 & $11.42 \pm 1.19$ & \\
\hline
\end{tabular}

Coelomocytes were comprised of $76.69 \%$ hyaline cells and $23.31 \%$ granular cells according to the presence or absence of granules (Table 2).

\section{Flow cytometry}

Three subpopulations were distinguished according to partial size as analyzed by flow cytometry (FCM) (Fig. 2). The dot plot showed coelomocyte size categories comparable to the results of LM. Group R1 had relatively large sizes and low densities and corresponded to the large granulocytes (Table 2). R2 had an intermediate size between R1 and R3, and may be the aggregation of the small granulocytes and the large

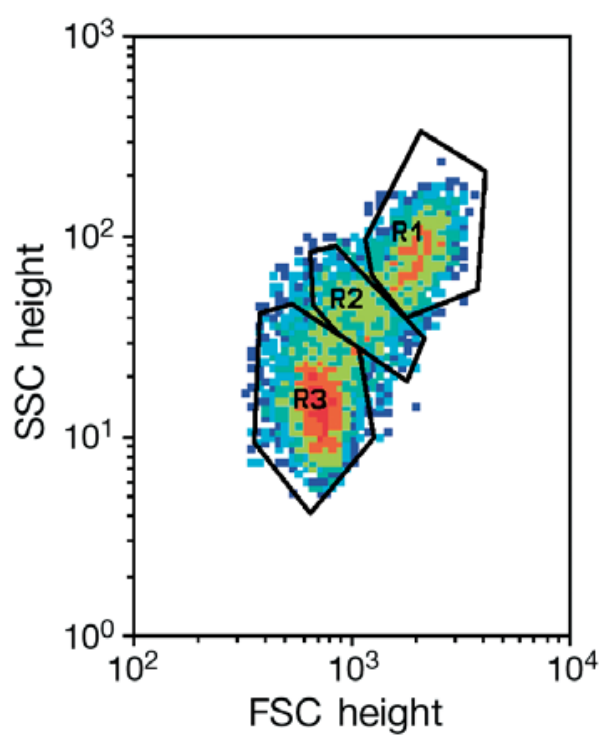

Fig. 2. Two-parameter flow cytometric separation of coelomocytes of the sea cucumber Apostichopus japonicus by forward scatter (FSC) and sideward scatter (SSC). Relative size (forward scatter) and complexity (sideward scatter) allowed identification of 3 main partial-sized distinct subpopulations of coelomocytes as demonstrated by a dot plot with gates on the hyalinocytes (R1), intermediate (R2) and granulocytes (R3) hyalinocytes. R3 types were much smaller and more abundant, corresponding to the small hyalinocytes (Table 2).

\section{Scanning electron microscopy}

Five types of coelomocytes could be identified on the basis of size and shape differences.

1. Round cells: The round cells might correspond to the lymphocytes identified using LM. These cells were small (about 2 to $4 \mu \mathrm{m}$ ) and abundant in all cell types. They were round with a relatively smooth surface (Fig. 3A); occasionally 2 pseudopodia occurred at opposite poles of the cell (Fig. 3B). 'Triangular' round cells had a filiform pseudopodium extension from each corner (Fig. 3C).

2. Amoebocytes: These cells were about $5 \mu \mathrm{m}$ in diameter. The surface contained various cytoplasmic pseudopodia (Fig. 3D).

3. Morula cells: These were spherical in shape, ranging in diameter from 8 to $20 \mu \mathrm{m}$; the small spherules inside were of uniform size ( 0.5 to $2 \mu \mathrm{m}$ diameter) and completely filled the cells (Fig. 3E).

4. Crystal cells: These were multifarious in shape, including styloid, cuboid, hexagonal and other shapes (Fig. 3F-I). The round nucleus was located at the periphery of the cell.

5. Fusiform cells: These usually were of pear or spindle shape, with relatively smooth surfaces; 2 long pseudopodia were located at opposite ends of the cell (Fig. 3J). Fusiform cells ranged from 2 to $4 \mu \mathrm{m}$ in diameter and from 15 to $20 \mu \mathrm{m}$ in length.

\section{Transmission electron microscopy}

Four coelomocyte types could be determined.

1. Lymphocytes: These were spherical cells about $3 \mu \mathrm{m}$ in diameter. A single, finely granulated spherical nucleus nearly filled the entire cell (Fig. 4A). These cells might correspond to the small hyalinocytes seen with LM and the round cells identified with scanning electron microscopy (SEM). A single electron-dense nucleolus was occasionally visible. The nucleus was surrounded by a thin ring of dense cytoplasm in which some mitochondria and several vacuoles occurred.

2. Amoebocytes: These cells possessed clear hyaline peripheral cytoplasm that produced pseudopodia and a granular perinuclear cytoplasm containing the single nucleus and various cytoplasmic inclusions. All the amoebocytes possessed either petaloid or filiform pseudopodia (Fig. 4B,C) that radiated in different directions from the central perinuclear cytoplasm of the cells. Amoebocytes were capable of clotting with 

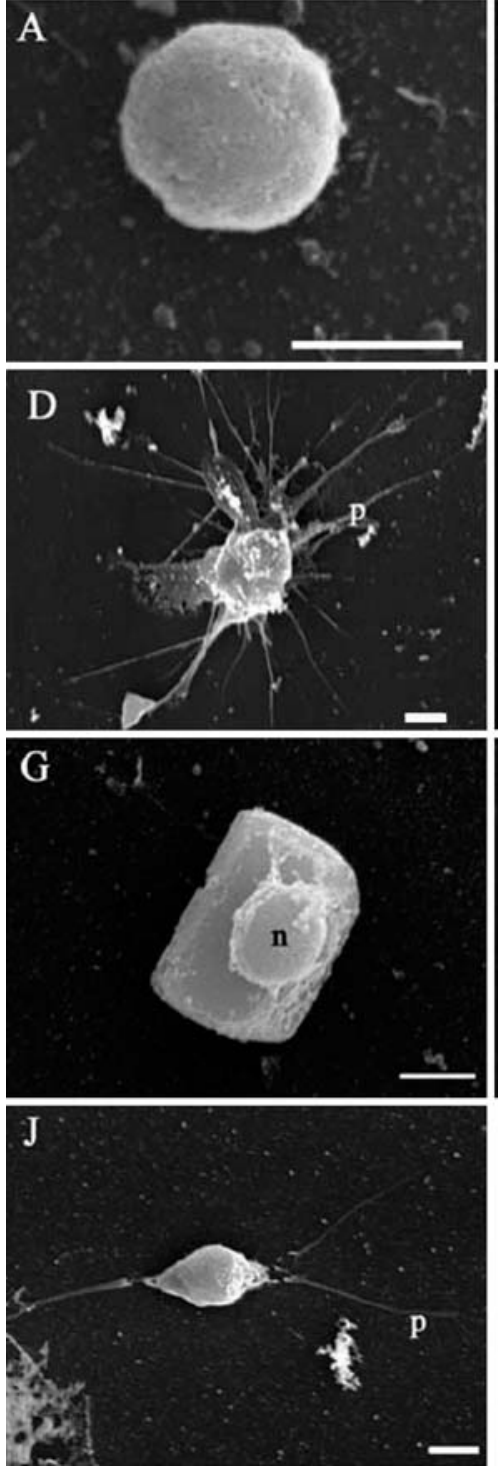
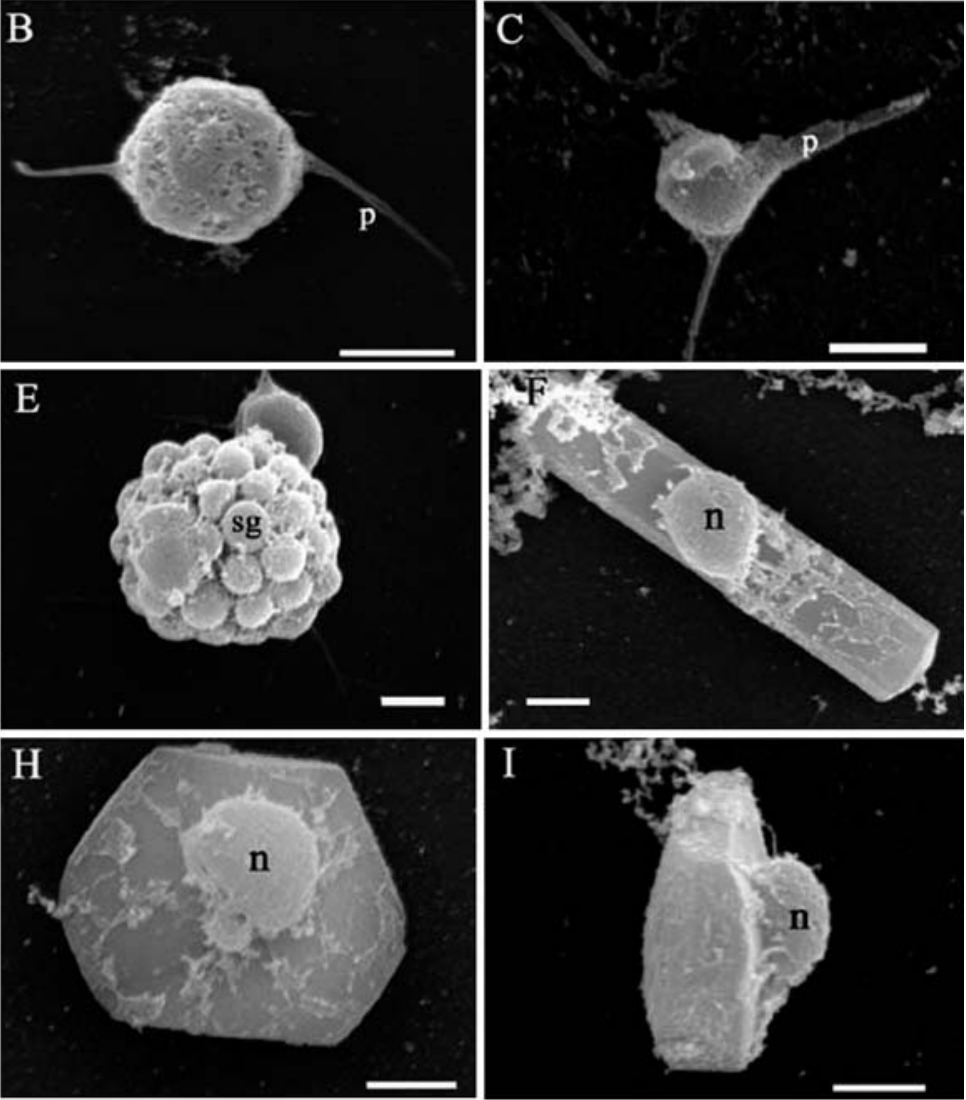

Fig. 3. Apostichopus japonicus. Scanning electron micrographs of coelomocytes of the sea cucumber. (A) Round cell; (B) round cell with 2 pseudopodia; (C) round cell with 3 pseudopodia; (D) amoebocyte; (E) morula cell; (F) styloid crystal cell; $(\mathrm{G})$ cuboid crystal cell; $(\mathrm{H})$ hexagon crystal cell; $(\mathrm{I})$ lateral view of a crystal cell; (J) fusiform cell. Labels - p: pseudopodia; sg: secretory granule; n: nucleus. Scale bars: $2 \mu \mathrm{m}$

filiform pseudopodia (Fig. 4D). The perinuclear cytoplasm contained rough endoplasmic reticulum (rer), mitochondria $(\mathrm{m})$, numerous vacuoles and phagosomes with electron-dense contents. Residual bodies (Fig. 4E) also were abundant in the cytoplasm. Amoebocytes were thought to phagocytose foreign particles and old cells. An entire degraded cell is shown enveloped by plasma membrane which involved the formation of a cystozooid (Fig. 4F).

3. Morula cells: These were spherical in shape filled with large secretory granules, mitochondria and Golgi complexes (Fig. 4H). They contained little cytoplasm, as most of the cell was occupied by densely packed secretory granules; the nucleus was usually irregular in shape. The granules of these cells differed in content; Type I morula cells contained heterogenous granules with a central electron-dense core and a loose fib- rillar shell (Fig. 4G); in Type II morula cells, the granules were homogenously electron dense (Fig. $4 \mathrm{H}$ ).

4. Fusiform cells: These possessed 2 long pseudopodia tapering from the ends of the cells (Fig. 4I), which exhibited a regular discoid shape.

\section{DISCUSSION}

Apostichopus japonicus shares many different morphological and structural characteristics with other holothurians. Hetzel (1963) reviewed classification of holothurian coelomocytes, and described at least 9 basic categories. In the present study, 6 types of $A$. japonicus coelomocytes (lymphocytes, amoebocytes, morula cells, crystal cells, fusiform cells and vibratile cells) are described. 

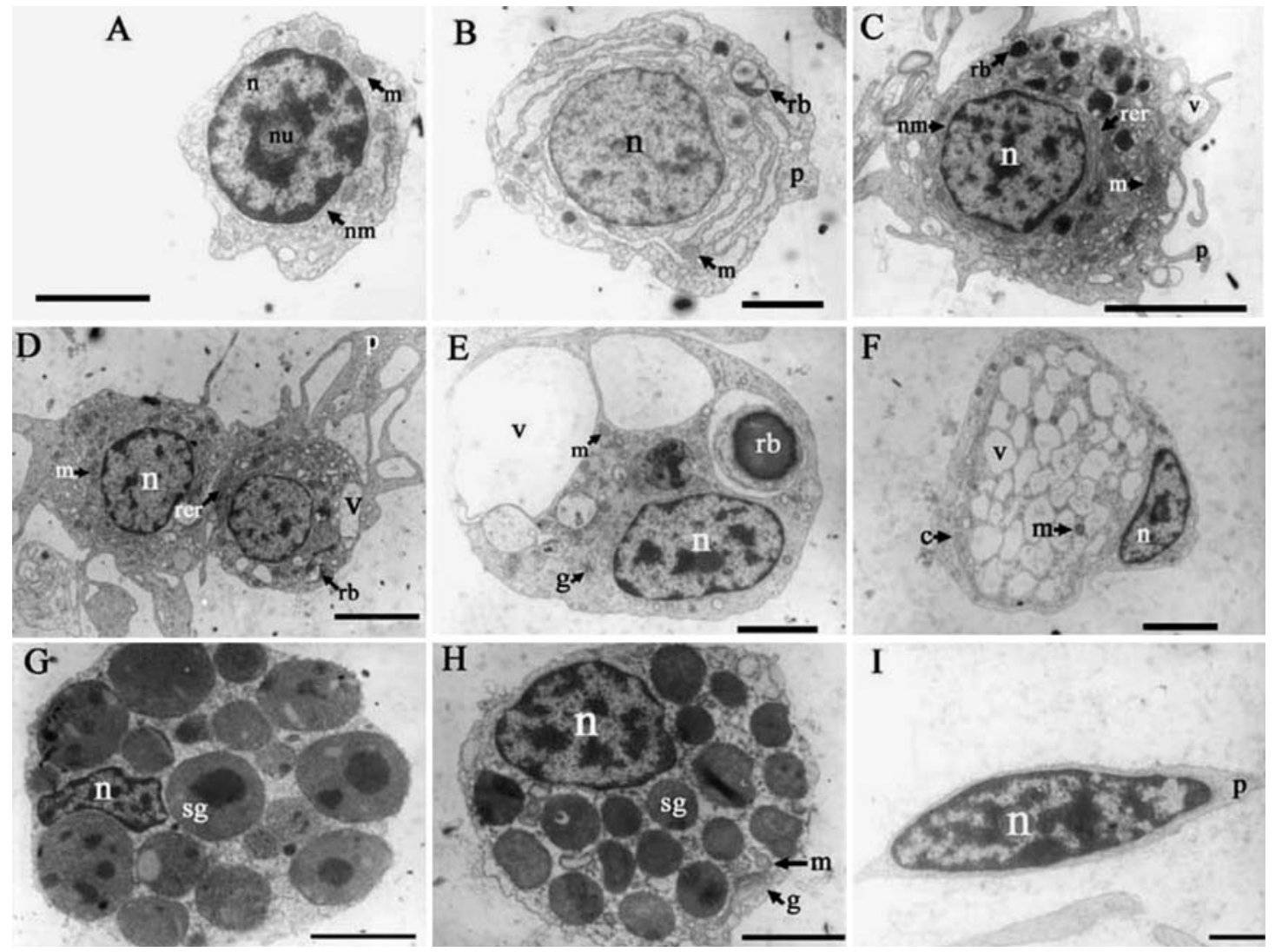

Fig. 4. Apostichopus japonicus. Transmission electron micrographs of coelomocytes of the sea cucumber. (A) Lymphocyte with thin cytoplasm; (B) petaloid amoebocyte; (C) filiform amoebocyte; (D) clotting of amoebocytes; (E) an old cell phagocytosed by an amoebocyte; $(\mathrm{F})$ void morula cell phagocytosed by an amoebocyte; $(\mathrm{G})$ heterogenous granules of a morula cell; $(\mathrm{H})$ homogenous granules of a morula cell; (I) fusiform cell. Labels - n: nucleus; nu: nucleoli; nm: nucleus membrane; m: mitochondria; p: pseudopodia; rb: residual bodies; rer: rough endoplasmic reticulum; v: vacuoles; g: Golgi complex; c: cystozooid; sg: secretory granules. Scale bars: $2 \mu \mathrm{m}$

We conclude from the literature and our findings that only lymphocytes, amoebocytes, morula cells and crystal cells are common cellular elements in the CF of Apostichopus japonicus, whereas fusiform cells and vibratile cells are not present in every specimen.

Lymphocytes are numerically dominant; their nucleus is typically prominent and the chromatin is moderately electron dense. This suggests that the lymphocytes are not very differentiated and, therefore, they may be the precursors of some types of coelomocytes. Accordingly, lymphocytes are often called progenitor cells (Chia \& Xing 1996, Eliseikina \& Magarlamov 2002). Several additional factors lend credibility to the hypothesis that these cells all may be derived from the lymphocytes that also give rise to amoebocytes. Specifically, the sparse cytoplasm contains few mitochondria, the lymphocytes are relatively smooth in outline, the pseudopodia are small and unbranched and never as complex as the branching filiform pseudopodia of amoebocytes, and the fusiform and vibratile cells are able to produce pseudopo- dia of some forms (Hetzel 1965, Eliseikina \& Magarlamov 2002).

Amoebocytes are the second most abundant cell type in the CF of Apostichopus japonicas and are interpreted to be amoeboid phagocytes. Amoebocytes are recognized to contain heterogenous materials of various sizes. These cells frequently have many pseudopodia, and amoebocytes with numerous pseudopodia often clump together. In the holothurian species studied, as well as in other echinoderms, the pseudopodia of the amoebocytes were petaloid and filiform (Edds 1993). Canicattí \& Farina-Lipari (1989) described dynamic transformations from petaloid to filiform stages in Holothuria polii. Careful observation of fresh preparations revealed that all amoebocytes possess pseudopodia that radiate in different directions from the central perinuclear cytoplasm of the cell. The amoebocytes present these morphological changes before and during cell aggregation; in fresh preparations the petaloid pseudopodia appear to collapse, and a redistribution of the cytoplasm produces branching 
filiform pseudopodia of considerable length, often intermingling with the filiform pseudopodia of other amoebocytes, which is referred to as clotting. Clotting is thought to be a defence mechanism against loss of $\mathrm{CF}$ when the body wall is punctured. Amoebocytes also function in the cellular encapsulation of foreign materials and microbes (Hillier \& Vacquier 2003). The residual bodies abundant in the cytoplasm may be old or damaged coelomocytes, and the elimination of these cells by amoebocytes from the CF was constant.

Morula cells are a common coelomocyte type in the $\mathrm{CF}$, containing granules in the cytoplasm, that are also found in ascidians and the dendrochirotid sea cucumber Eupentacta quinquesemita (Ballarin et al. 2005, Byrne 2005). Morula cells are characterized by a compressed and even irregular nucleus, and numerous electron-dense granules. These granules contain proteins, suggesting that they are secreted and function as extracellular digestive enzymes (Massin 1980). Byrne (2005) described the ultrastructure of the morula cells of E. quinquesemita in the dermis, and thought these cells to function in the maintenance of the extracellular matrix as a source of ground substance material. Morula cells are referred to as trephocytes, which participate in food storage and the synthesis of many humoral factors of the echinoderm immune system and extracellular matrix of connective tissue. Morula cells are divided into different types. In Type I cells, granules are heterogenous and contain a central electrondense core, consisting of proteins, lipids and neutral polysaccharides, surrounded by a loose fibrillar shell that is composed of acid polysaccharides (Massin 1980, Eliseikina \& Magarlamov 2002). In Type II cells, granules are homogenously electron dense and consist of glycoproteins (Eliseikina \& Magarlamov 2002). In addition to the 2 morula cell types described above, we also found cells with vacuoles similar in size to the granules, but appearing to lack contents at the ultrastructural level, with no electron-lucent granules stained by any of the vital dyes used. When the morphology and structure of the 3 different morula cells is compared, similarity, continuity and coherence appear to be strong and apparent.

The crystal cells are multifarious in shape, including styloid, cuboid, hexagonal and other shapes. The thin layer of hyaline cytoplasm surrounding crystal cells is visible only when viewed from a favourable angle. The single nucleus is often flattened and closely applied to the crystal cells. Hetzel (1963) reported that the crystal cells were not found in the fixed materials, because they dissolved under the slightest osmotic stress or were lost during the staining and dehydration process. However, we identified crystal cells with SEM, but did not observe them with TEM. The crystal cells of Apostichopus japonicus are larger and more complex in form than in other holothurians. This suggests that crystal cells participate in osmoregulation (Eliseikina \& Magarlamov 2002). As the osmotic pressure changes, a reversible crystallization of the intravacuolar material occurs, thereby normalizing the osmotic pressure. Hetzel (1963) suggested that the crystal cells were related to the mesenchymal ossicle-forming cell of the body. However, these hypotheses need further study.

Except for the common types of coelomocytes mentioned above, fusiform cells and vibratile cells appear to be distinctive in appearance and limited in distribution among species. Fusiform cells and vibratile cells are occasionally observed in fresh preparations of CF. Their relative numbers increase with repeated handling and sampling from a given specimen. Two long pseudopodia tapering at ends of the cells are evident in fusiform cells.

In living preparations, vibratile cells are similar in structure and size to young amoebocytes, but possess a long flagellum and swim rapidly through the fluid. We are unsure of the origin of the vibratile cells. Hetzel (1963) considered these irregular cells to be contaminants of some kind or to be protozoan symbionts. Surface contaminants on Apostichopus japonicus could easily have been introduced into the sample by the needle inserted into the organism. Mary (1972) thought that the vibratile cells originated in the peritoneum. Lecal (1980) even observed an endoparasitic flagellate of the genus Cryptobia in the coelomic fluids of Antedon bifida Pennant. Matranga et al. (2006) described the round vibratile cells with a long flagellum moving in a straight direction in Paracentrotus lividus along a helicoidal path. Few have studied the morphology of the vibratile cells because of their fast movement (Matranga \& Bonaventura 2002), and their function is currently debated. An attractive hypothesis is that vibratile cells contribute to the continuous circulation of the perivisceral CF generated by the ciliated coelomic epithelium (Ruppert \& Barnes 1994). The vibratile cells had longer and more conspicuous flagellum-like extensions that were markedly different from the flagellated endoparasites; the appearance of the vibratile cells was also interpreted as the development of amoebocytes in the peritoneum (Mary 1972). These interpretations established them as endogenous members of the coelomocyte population. It has been suggested that vibratile cells function in keeping the $\mathrm{CF}$ in motion by the lashing of their vibratile processes.

Haemocytes containing haemoglobin are found extensively in the class Holothuroidea in the perivisceral coelom and the water vascular system. Haemocytes are widely distributed among members of the orders Dendrochirotida and Molpadida, but Aspidochirote holothurians, including Apostichopus japon- 
icus, are devoid of haemocytes, as has been reported in the related literature (Hetzel 1963, Robert \& Nora 1988, Eliseikina \& Magarlamov 2002). Much remains to be learned about the structure and function of the various coelomocyte types before the immunology and physiological ecology of $A$. japonicus can be fully understood.

Acknowledgements. The work was supported by the National Natural Science Foundation of China (No. 40576073). Prof. Jiang Ming, Prof. Sheng Xiuzhen, Prof. Sun Li, Mrs. Barbara Kieser, Mrs. Xie Jialin and Mr. Liu Wei have provided facilities and assistance; we are grateful for their help and information.

\section{LITERATURE CITED}

Ballarin L, Parisotto F, Cima F (2005) Morula cells and nonfusion reaction in the compound ascidian Botryllus schlosseri. In: Proc of the 7 th scientific meeting of the Italian Association for Developmental and Comparative Immunology (IADCI). Consorzio Universitario Provincia di Trapani, Trapani

Byrne M (2005) The ultrastructure of the morula cells of Eupentacta quinquesemita (Echinodermata: Holothuroidea) and their role in the maintenance of the extracellular matrix. J Morphol 40:179-189

Canicattí C, Farina-Lipari E (1990) Dynamic and morphological aspects of coelomocyte clotting in Holothuria polii. J Invertebr Pathol 56:63-69

Chia F, Xing J (1996) Echinoderm coelomocytes. Zool Stud 35:231-254

> Dolmatova LS, Eliseikina MG, Romashina VV (2004) Antioxidant enzymatic activity of coelomocytes of the Far East sea cucumber Eupentacta fraudatrix. J Evol Biochem Physiol 40:126-135

Edds KT (1993) Cell biology of echinoid coelomocytes. I. Diversity and characterization of cell types. J Invertebr Pathol 61:173-178

Eliseikina MG, Magarlamov TY (2002) Coelomocyte morphology in the holothurians A. japonicus (Aspidochirota: Stichopodidae) and Cucumaria japonica (Dendrochirotida: Cucumariidae). Russ J Mar Biol 28:197-202

Gross PS, Al-Sharif WZ, Clow LA, Smith LC (1999) Echinoderm immunity and the evolution of the complement system. Dev Comp Immunol 23:429-442

Hetzel HR (1963) Studies on holothurian coelomocytes. I. A survey of coelomocyte types. Biol Bull 125:289-301

> Hetzel HR (1965) Studies on holothurian coelomocytes. II. Origin of coelomocytes and the formation of brown bodies. Biol Bull 128:102-111

Editorial responsibility: Victor Benno Meyer-Rochow, Bremen, Germany
Hillier BJ, Vacquier VD (2003) Amassin, an olfactomedin protein, mediates the massive intercellular adhesion of sea urchin coelomocytes. J Cell Biol 160:597-600

Holland ND (1984) Echinoderm epidermal cells. In: Bereierthan J, Matoltsy AG, Rithards KS (eds) The biology of the integument, Vol. 1. Invertebrates. Springer-Verlag, Berlin, p 756-774

Hyman LH (1955) The invertebrates. Echinodermata, Vol. 4. McGraw-Hill, New York

Lecal L (1980) Etude des coelomocytes d'un Crinoïde, description de Cryptobia antedona, n.sp., Zooflagellé Bodonidé du coelome général d'Antedon bifida (Pennant). In: Jangoux MJ (ed) Echinoderms: present and past. Proc European Colloquium on Echinoderms, Brussels, 3-8 September 1979. Balkema, Rotterdam, p 271-275

Liu Y, Tan JS, Bao ZM, Xie JL (2005) Ultrastructural study on coelomocyte of Apostichopus japonicus. J Chin Electron Microsc Soc 24:613-615

Mary SG (1972) Transport mechanisms. In: The biology of invertebrates. McGraw-Hill, New York, p 399-405

Massin C (1980) Morphologic fonctionnelle du tube digestif d'Holothuria tubulosa Gemlin (Echinodermata: Holothuroidea). In: Jangoux MJ (ed) Echinoderms: present and past. Proc European Colloqium on Echinoderms, Brussels, 3-8 September 1979. Balkema, Rotterdam, p 261-270

Matranga V, Bonaventura R (2002) Sea urchin coelomocytes, the progenitors of vertebrate immune effectors, as bioindicators of stress and pollution. In: Yokota Y, Matranga V, Smolenicka Z (eds) The sea urchin: from basic biology to aquaculture. Swets and Zeitlinger, Lisse, p 61-176

Matranga V, Pinsino A, Celi M, Bella GD, Natoli A (2006) Impacts of UV-B radiation on short-term cultures of sea urchin coelomocytes. Mar Biol 149:25-34

Messer LI, Wardlaw AC (1980) Separation of the coelomocytes of Echinus esculentus by density gradient centrifugation. In: Jangoux MJ (ed) Echinoderms: present and past. Proc European Colloqium on Echinoderms, Brussels, 3-8 September 1979. Balkema, Rotterdam, p 319-323

Noble PB (1970) Coelomocyte aggregation in Cucumaria frondosa: effect of ethylenediaminetetra-acetate, adenosine, and adenosine nucleotides. Biol Bull 139:549-556

Robert CT, Nora BT (1988) Structure and function of holothurian hemoglobins. In: Burke RD (ed) Echinoderm biology. Balkema, Rotterdam, p 589-595

Ruppert EE, Barnes RD (1994) Invertebrate zoology, 6th edn. Saunders College Publishing, Philadelphia

Santiago-Cardona PG, Berríos CA, Ramírez F, García-Arrarás JE (2003) Lipopolysaccharides induce intestinal serum amyloid A expression in the sea cucumber Holothuria glaberrima. Dev Comp Immunol 27:105-110

Smith LC, Britten RJ, Davidson EH (1992) SpCoel1: a sea urchin profiling gene expressed specifically in coelomocytes in response to injury. Mol Biol Cell 3:403-414

Submitted: October 9, 2007; Accepted: February 27, 2008

Proofs received from author(s): March 19, 2008 